\title{
Party Competition and Policy Liberalism
}

\author{
Zachary D. Baumann $^{1}$, Michael J. Nelson ${ }^{2}$ (D) and Markus Neumann ${ }^{3}$ \\ ${ }^{1}$ Department of Political Science, Nebraska Wesleyan University, Lincoln, Nebraska, USA \\ ${ }^{2}$ Department of Political Science, Pennsylvania State University, University Park, Pennsylvania, USA \\ ${ }^{3}$ Wesleyan University, Middletown, CT, USA \\ Corresponding Author: Michael J. Nelson Email: mjn15@psu.edu
}

(Received 29 May 2019; Revised 11 March 2020; Accepted 19 June 2020)

\begin{abstract}
Party competition is foundational to the study of modern politics, affecting outcomes as varied as policy choices, political participation, and the quality of representation. Scholars have long argued that increased levels of party competition are associated with more liberal policy making. By this logic, parties in close competition with one another try to expand their bases of support by catering to the desires of those who tend to abstain from the political process-the "have-nots." We extend this classic hypothesis by examining the relationship between competition and policy liberalism over several decades, articulating and testing a theory that suggests that party competition relates differently to social and economic policy liberalism. We find robust evidence that increased competition has a positive relationship with economic policy liberalism, weaker evidence for a negative relationship between competition and social policy liberalism, and suggestive evidence that the direction and magnitudes of these relationships have changed over time.
\end{abstract}

Keywords: parties and elections; parties in legislatures; political participation; economic policy; morality policy

\section{Introduction}

Political scientists have studied the development of political parties and their effect on policy making for decades (e.g., Campbell 1977; Downs 1957; Key 1949; Schattschneider 1960). The direction of public policy is often thought to depend, in part, on the party controlling government and the preferences of their electoral coalition. In some places and times, a single party is dominant and has little chance of losing office in the next election (e.g., Key 1949); in other places and times, the major parties routinely alternate power. Scholars term the vigor with which parties alternate power party competition.

Party competition is one of the most important concepts in the study of state politics. Ranney (1965) claims that "of all the variables studied in the analysis of state party politics, the one receiving the most attention from political scientists has been "inter-party competition"” (63). Similarly, Jewell (1982) calls the concept "[o]ne of the most important dimensions along which states differ" (6).

\footnotetext{
(c) The Author(s), 2021. Published by Cambridge University Press on behalf of the American Political Science Association. This is an Open Access article, distributed under the terms of the Creative Commons Attribution licence (http:// creativecommons.org/licenses/by/4.0/), which permits unrestricted re-use, distribution, and reproduction in any medium, provided the original work is properly cited.
} 
Perhaps the most significant hypothesis involving party competition and policy making in the American states is its relationship to the ideological leaning of the laws produced. The conventional wisdom, dating back to Key (1949) and Schattschneider (1960), establishes a crystal clear prediction: higher competition should be associated with more liberal policies. This relationship has received widespread support, leading one prominent scholar to go as far as to state that "Expectations about the effects of competition on policy-making are unambiguous" (Barrilleaux 1997, 1462). Unfortunately, most tests of this theory have relied on data encompassing only single policy areas or relatively short time periods. Moreover, these studies tend to treat state policy making as homogeneous, either because they generalize from a single issue area or because they rely upon measures that do not distinguish among types of state policies.

This paper reexamines the relationship between policy liberalism and party competition, building on previous scholarship in two ways. First, we take advantage of new advances in data availability to examine the relationship between these two concepts over a longer time horizon and across a broader array of policy areas. Most existing studies look only at a decade or two and at a small slice of economic policy. Our study, by contrast, examines the effects of party competition on economic and social policy liberalism since the Great Depression, enabling us to probe the generalizability of this theory over time and across issue domains.

Second, we expand on earlier theories by distinguishing between social and economic policy, exploring the effect of party competition on each of these policy areas separately. Key's (1949) landmark study focuses on economic policy, finding higher levels of interparty competition are associated with the expansion of the electorate, bringing routine nonvoters to the ballot box. These nonvoters tend to be society's "have-nots," people with low incomes whose interests are traditionally excluded from policy creation by their more economically advantaged neighbors.

In contrast to Key, we also explore the effect of competition on social policy. We argue that, while party competition has the positive effect on economic liberalism that Key (1949), Schattschneider (1960), and Barrilleaux (1997) suggest, it has the exact opposite effect on social liberalism: more competitive electoral environments lead to less social policy liberalism. This expectation is based upon the fact that class-level preferences on social policy cross-cut positions on social issues; higher income Americans tend to have socially liberal but economically conservative preferences while the converse is generally true from lower income Americans (Flavin 2011; Rigby and Wright 2013). Because the haves and have-nots tend to have divergent preferences over these bundles of policy, we expect that higher levels of party competition will have different effects for social and economic policy liberalism.

This paper is organized as follows: first, we review the literature on policy making and competition. Next, we develop a theory explaining why party competition is associated with more liberal economic policy and more conservative social policy. Third, we discuss the data we bring to bear on this question and the methods of analysis we employ. Fourth, we examine the relationship between party competition and policy liberalism from multiple perspectives. We conclude that party competition is related to more liberal economic policies and more conservative economic policies; however, the link between competition and social policy is less robust than its relationship with economic policy. We end by discussing the practical implications of these results and the impact they have on our theory. 


\section{Making Policy in the American States}

Commonly, four factors predominate explanations of state-level policy making: public opinion (Erikson, Wright, and McIver 1989, 1993), the ideology of the lawmakers serving in government (Entman 1983; Erikson, Wright, and McIver 1989, 1993), the party controlling the policy making process (Dye 1984; Erikson, Wright, and McIver 1989, 1993; Garand 1985), and the degree of competition between these parties (Barrilleaux 1997, 2000; Davies and Worden 2009). First, regarding public opinion, states with more liberal citizens are more likely to produce liberal policies (Erikson, Wright, and McIver 1993). Second, the ideology of legislators affects their roll call votes; liberal members tend to vote for liberal policies (Entman 1983).

While these first two factors are fairly robust predictors of the ideological valence of state policy, the relationship between party control, party competition, and policy making is less clear. ${ }^{1}$ Some research demonstrates Democratic control of government corresponds to more liberal policies (Dye 1984; Garand 1985) while others find the opposite (Erikson, Wright, and McIver 1989). To square these disparate conclusions, Barrilleaux $(1997,2000)$ examines the interactive effect of competition and partisanship on policy making. These studies demonstrate that party competition increases policy liberalization and that, absent interparty competition, both Democrats and Republicans are unlikely to modify their positions (Barrilleaux 1997, 2000).

The importance of party competition for effective governance has been underscored by several scholars. Ranney (1965) argues that:

Most writers on the subject of state politics believe that a state's competitiveness is significantly related to other characteristics of its parties and politics ... they generalize that the state parties facing the closest competition are likely to have the most centralized control of nominations, and the highest cohesion in state legislatures and in gubernatorial-legislative relations. Consequently, they are likely to be the most effective and responsible governing agencies (63).

Ranney does not stand alone. Aldrich (2011) draws a connection between party competition and the quality of governance: " $[\mathrm{t}]$ he South was solidly Democratic for a century, machines ruled in many cities and in some rural areas, and in such areas of one-party dominance there was for long periods effectively no competition for office by the opposing party. Thus articulation, aggregation, and accountability were all lost" (13, see also Aldrich and Griffin (2018)). Scholars have long believed that high levels of interparty competition will incentivize parties to improve the quality of representation they provide.

Many of these conclusions are generated, however, by examining a single policy area or by examining many laws during only a single year. For example, Dye (1984) and Barrilleaux, Holbrook, and Langer (2002) examine the relationship between electoral competition and welfare policy while Erikson, Wright and McIver (1993)

\footnotetext{
${ }^{1}$ It is important to separate the desires of individual candidates and legislators from the goals of the party. While parties are both exogenous from, and endogenous to, candidates and policy makers, they have a duty to maintain their strength and assemble majority coalitions. Individual lawmakers may be incentivized to run toward their electoral base to secure future campaign resources, but parties must craft an agenda and platform that resonates with the state public at-large. While both parties are responsible for pushing policy in a decidedly ideological position (Dye 1984; Erikson, Wright, and McIver 1989, 1993; Garand 1985), they must advance an agenda that appeals to the whole state or risk all of their candidates appearing out of touch.
} 
examine the correlation across a cross-sectional measure of state policy liberalism. While each of these studies has represented an important advance in our understanding of state policy making, studies relying on single policy areas or single points in time raise questions of generalizability across policies or time.

We are fortunate that new, dynamic measures of state policy liberalism exist. Caughey and Warshaw (2016) develop a measure of policy liberalism based on nearly 150 different policies dating back to the 1930s that is comparable across states and years. Caughey and Warshaw (2018) extend this data collection effort, creating separate measures of social and economic policy liberalism. Caughey and Warshaw use separate measurement models to estimate state-year estimates of social policy liberalism and economic policy liberalism based on the presence or absence of particular policies in a given state-year. As a result, a state-year's estimate for one type of liberalism does not affect that state-year's estimate for the other type of liberalism. The availability of new data allows us to reexamine these questions while differentiating between types of policies.

\section{Why Competition May Lead to Liberal Policy Making}

Traditional expectations for the relationship between party competition and policy liberalism see variation in electoral participation as the glue that binds competitive elections and liberal state policies. High levels of competition are associated with increased levels of electoral participation (Flavin and Shufeldt 2015); therefore, the argument goes, high rates of competition should increase the quality of representation by encouraging parties to expand the voters they target. Blais (2000), summarizing 32 studies across time, space, and method, writes that there is a "crystal clear" relationship between the closeness of an election and turnout: individuals are more likely to vote in close elections (60). Moreover, the effect of closeness is not limited to increased spending by candidates or parties on mobilization (Blais 2000). Parties in close competition with one another are expected to increase their base by targeting voters they believe will turn out. In these cases, parties must choose between doubling-down on the same policies their base already supports or modifying their position to attract the support of those who traditionally do not participate and whose interests may not currently be well-represented by either party.

The traditional explanation linking competition and policy liberalism favors the latter strategy: parties respond to increasing competition by targeting the have-nots (Davies and Worden 2009; Downs 1957; Holbrook and Van Dunk 1993; Key 1949). These have-nots are marginal voters - the sort of people who are likely to turn out in competitive elections but not in landslide elections-and their policy preferences tend to be less represented under low party competition. As originally theorized, these are voters with low incomes who are not regularly participating in the electoral process. Key (1949) argues that:

Politics generally comes down, over the long run, to a conflict between those who have and those who have less. In state politics the crucial issues tend to turn around taxation and expenditure... [O]ver the long run the have-nots lose in a disorganized politics. They have no mechanism through which to act and their wishes find expression in fitful rebellions led by transient demagogues who gain their confidence but often have neither the technical competence nor the stable base of political power to effectuate a program (307). 
Key is not alone. Indeed, Schattschneider (1960) contends that "one-party politics tends to strongly vest political power in the hands of people who already have economic power" (80). Areas with low competition tend to have conservative policies because elites have little need to represent the more liberal preferences of the have-nots.

Increased electoral participation can remedy this conservative bias. Key (1949) writes: "The have-have-not match is settled in part by the fact that substantial numbers of the have-nots never get into the ring. For that reason, professional politicians often have no incentive to appeal to the have-nots" (308). ${ }^{2}$ Because higher levels of competition tend to foster higher turnout elections and those nonhabitual voters that only turn out in competitive elections tend to be have-nots, politicians facing high levels of competition are incentivized to appeal to a more liberal electorate than they would otherwise target.

More recent scholarship has validated Key's intuition. Hill and Leighley (1992) demonstrate there is a negative relationship between a class bias in state electorates and redistributive state policies; more generous redistributive policies are associated with the participation of the poor in the electoral politics. Hill, Leighley, and Hinton-Anderson (1995) examine the relationship between the mobilization of lower-class voters and the generosity of a state's welfare policy, demonstrating that higher rates of lower-class voting are associated with more generous welfare policies, exactly as Key suggested.

Taken together, Key and others suggest that, because (a) party competition increases electoral participation and (b) those mobilized by this competition tend to be have-nots who favor liberal policies, (c) increased party competition should lead policy makers to pass policies that are more liberal than those they would have passed in the absence of such competition.

\section{Is This Always True?}

States pass a heterogeneous bundle of policies. Some issues are more salient than others to voters and, by extension, more important in electoral campaigns (Bianco 1994; Carmines and Stimson 1980; Carpini, Keeter, and Kennamer 1994; Jennings and Zeigler 1970; Kingdon 1966; Stokes and Miller 1962). One major distinction between policies concerns whether they affect economic or social issues. Existing explanations linking competition to policy liberalism tend to focus on either economic policy (e.g., Barrilleaux 1997) or a bundle of state policies (e.g., Erikson, Wright, and McIver 1993). This makes sense; in his original formulation of this expectation, Key (1949) refers specifically to economic policy. We extend this theory to the domain of social policy, as well.

Social policy differs from economic policy in several important ways. First, much of a state's budget is constrained by their laws and constitution, level of indebtedness, amount of federal transfers, and economic health (Bunche 1991; Poterba 1994). While lawmakers may desire to move the budget strongly in one direction, they are often stymied by the economic realities and legal environment in which they operate. Second, social policy is easier for citizens to understand and take positions on (Carmines and Stimson 1980). These issues attract more attention and parties may come to believe their electoral fortunes ride more highly on these bills. While it is

\footnotetext{
${ }^{2}$ Schattschneider sang a similar tune: "in one-party areas (areas of extreme sectionalism) votes decline in value because the voters no longer have a valuable party alternative" leading to low voter turnout (180).
} 
unlikely that citizens will take firm positions on the allocation of the state's budget, it is far more likely that they can express an opinion on a social concern (e.g., abortion) and remain invested in this position for a considerable length of time. Finally, there is empirical support for high degrees of policy responsiveness among social policies (Lax and Phillips 2009, 2012). While there is qualified support for policy responsiveness on economic issues (Pacheco 2013), its effect is stronger when examining social issues, like gay rights (Lax and Phillips 2009). For these reasons, Caughey and Warshaw (2018) note that policy responsiveness to voters should be weaker on economic issues than social issues.

Perhaps most importantly, however, class-level preferences on social policy crosscut their positions on social issues. For example, Flavin (2011) reports that lowincome citizens are $6 \%$ more likely to report a belief that abortion should be banned completely, compared to high-income citizens. Similarly, Ansolabehere, Rodden, and Jr. (2006) find that lower-class voters are more conservative on moral issues than upper-class voters. Gilens (2009) reaches a similar conclusion in his analysis of more than 1,700 survey questions; while low-income Americans are strong supporters of many redistributive policies, they tend to be more conservative on many social issues, including abortion policy, stem cell research, and gay rights. ${ }^{3}$

In short, and as Rigby and Wright (2013) explain, "higher-income Americans tend to be more conservative than the poor on economic issues, but more liberal on social and moral issues" (554). Figure 1 illustrates this relationship, plotting the smoothed distribution of economic and social attitudes by socio-economic status from Rigby and Wright (2013). Those authors measure average attitudes for citizens with low, middle, and high income (divided into equally-sized groups by state income percentiles) for 47 states in the year 2000. Economic attitudes are distributed as expected: The citizens with the lowest socio-economic status (SES) have the most economically liberal attitudes, and the differences between the three income classes are fairly pronounced. For example, the most liberal respondents in the high-income group are about as liberal as the average respondent in the low-income group. On the social policy dimension, the ordering of the three groups is reversed. On issues of social policy, low-SES citizens have the most conservative attitudes. Importantly, however, the differences in social attitudes between the three groups are not as large as on the economic dimension. At the conservative end of the spectrum, the three groups are almost equally well-represented, and while high-income respondents lean liberal, there is still a substantial number of them on the conservative side.

This cross-cutting opinion structure suggests that the relationship between overall policy liberalism and competition may differ on social issues than economic issues. Increased competition incentivizes politicians to appeal to marginal voters, and marginal voters tend to have preferences aligned with the have-nots in society. Moreover, have-nots have cross-cutting preferences on social and economic issues. Therefore, we expect:

$H_{1}$ : Increased party competition is associated with increased economic liberalism. $\mathrm{H}_{2}$ : Increased party competition is associated with decreased social liberalism.

\footnotetext{
${ }^{3}$ This view is not unanimous. Soroka and Wlezien (2008) argue that "differences in preferences across income brackets are in fact small and insignificant" (309).
} 


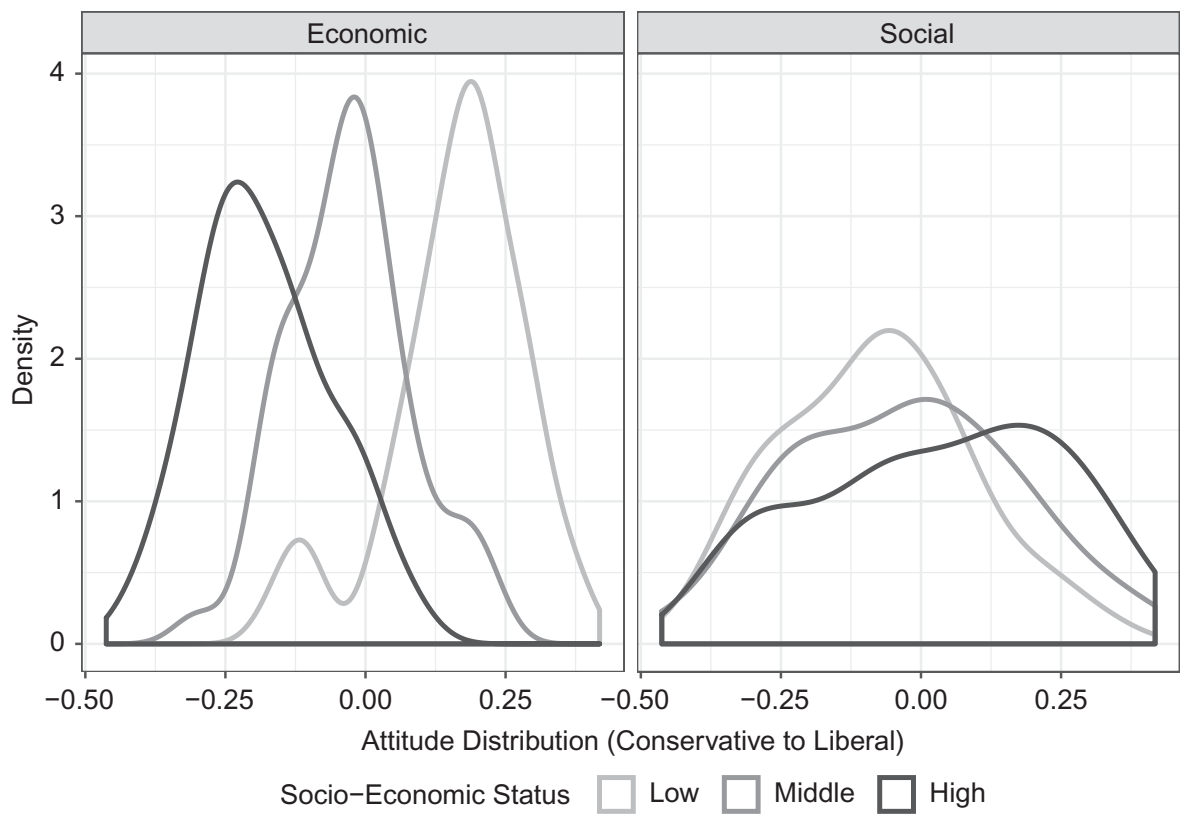

Figure 1. Smoothed distribution of economic and social attitudes by socio-economic status. Data from Rigby and Wright (2013).

\section{Research Design and Data}

Testing these hypotheses requires repeated measures of policy liberalism and party competition for each state over time. We now describe how we operationalize these concepts, provide descriptive statistics for each, and explain our strategy for assessing our hypotheses.

We test our hypotheses using measures of economic and social policy liberalism estimated by Caughey and Warshaw (2018). These variables, which are the output of a latent variable model incorporating information on the adoption of nearly 150 policies between 1936 and 2014, range from -2.49 to 2.61 (Social) and -2.24 to 3.13 (Economic). Both variables have a mean of 0 and standard deviations of 0.85 (Social) and 0.93 (Economic).

Figure 2 shows the median values of the two variables by year. Overall, there is no clear trend in the series by year (a bivariate regression yields $p$-values of $p=0.1$ Social and $p=0.26$ Economic for the slopes). Unsurprisingly, the two measures are highly correlated: $r=0.71$. Conceptually, there are some differences between the two series. Many of the economic policies that Caughey and Warshaw (2018) use to construct their measures are effectively dials that states can use to change their level of economic policy liberalism very gradually. For example, a state might adjust its tax on a pack of cigarettes, or the level of benefits from the Aid for Families with Dependent Children program by a few percentage points. By contrast, social policies such as the death penalty, or the legality of same-sex marriage, are more akin to levers which are either on or off. Consequently, social policy moves more slowly within a state, but when changes do occur, they can be more erratic. The Caughey and 


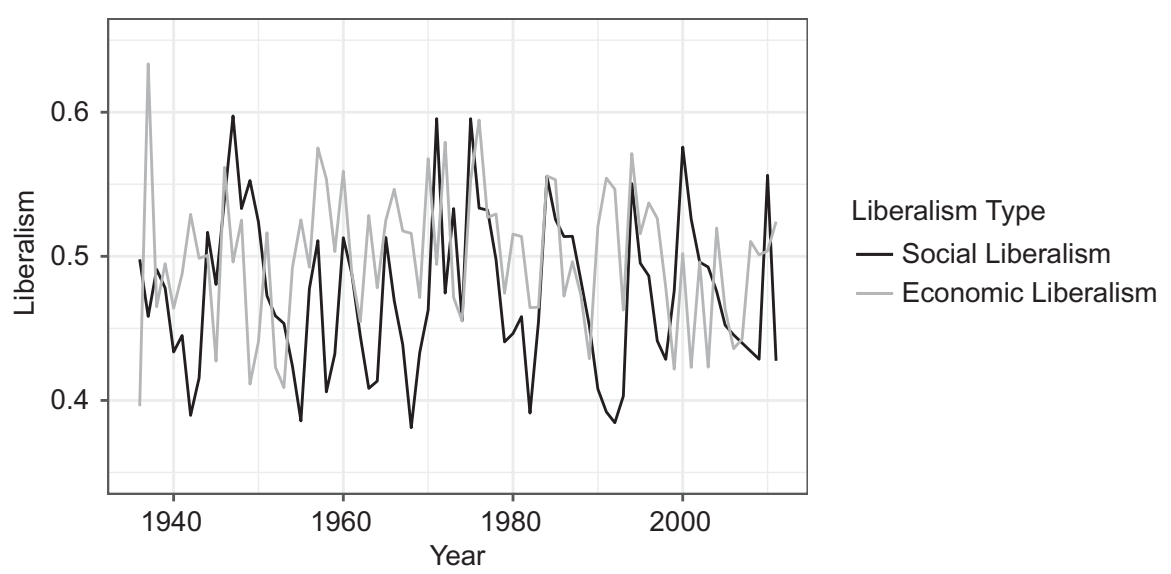

Figure 2. Median values of policy liberalism, by year. Data from Caughey and Warshaw (2018).

Warshaw (2018) model includes both continuous and binary variables, but for some state-years, only binary social policy items exist. As a result, the model has no continuing time series of an interval-level variable to "tether" itself to from year to year. As a result, the standard errors for these estimates are larger.

To measure party competition, we turn to the Folded Ranney Index. The original (unfolded) Ranney Index measures the competitiveness of the party in government by including the proportion of seats won by the Democratic party in the legislature, the percent of the vote received by the Democratic candidate for governor, and the percent of the time Democrats control both the executive and legislative branches (Ranney 1976). A single score is calculated by averaging these three items together over a number of years to account for the timing of gubernatorial and legislative elections as well as to smooth out high and low values that may be the product of one aberrant election cycle. The Ranney Index, therefore, measures the strength of the Democratic (or Republican) party in government. Scholars interested in the level of competition between the parties for control of government more explicitly have "folded" the Ranney Index over its midpoint to create a measure where higher values are associated with more competition and lower values, one-party dominance. The variable ranges from 0.50 to 1.00 with a median of 0.86 and a standard deviation of $0.13 .^{4}$

\footnotetext{
${ }^{4}$ Our focus in this paper is party competition, rather than electoral competition. Party competition refers to the frequency with which the major parties alternate control of government. Ranney (1976), for example, measures this concept by assessing the number of seats a party holds in the legislative branch, the party's control of the executive branch, and the presence of unified government. Electoral competition, by contrast, refers to the vulnerability of a given legislator seeking reelection absent partisan considerations. In early studies, this concept was operationalized by comparing the votes received by the winner to the candidate receiving the next most (Jewell and Breaux 1988; Weber, Tucker, and Brace 1991) or aggregating the margin of victory to the state level (Anderson 1997; Berry, Berkman, and Schneiderman 2000). More recently, Holbrook and Van Dunk (1993) developed a state-level measure of electoral competition that incorporates the percent of votes received by the winning candidates, their margin of victory, the number of seats considered safe, and the number of races in which both major parties are running a candidate. While these two concepts are positively correlated, they are distinct conceptually (Shufeldt and Flavin 2012) and often
} 
Our unit of analysis is the state-year, and our dataset is a panel. Each of our outcome measures is continuous, so we rely on linear regression to test our hypotheses. We estimate a series of regression models using two-way state and year fixed effects to account for within-state and within-year confounding factors. To assess the robustness of our findings to various aggregations of the Folded Ranney Index, we estimate each model using 4-, 6-, 8-, and 10-year time aggregations for each measure of competition. Our data begin in the late 1930s (depending on the time aggregation) and end in 2010.

Because we employ fixed effects for state and year, the gravest threats to inference are confounding factors that vary within states over time and are related to both competition and policy liberalism. ${ }^{5}$ Therefore, in addition to estimating the bivariate relationship between competition and policy liberalism, we also estimate another series of models that included lagged controls for several factors-public opinion, gubernatorial control, legislative control, and the percentage of Black citizens-that relate to both policy liberalism and competition and vary within states over time.

First, Caughey and Warshaw (2018) provide measures of public opinion toward social and economic liberalism; we include those variables in the models that assess those concepts. Again, these variables are the output of a latent variable model; they range from -1.25 to 2.04 (Social) and -0.93 to 0.65 (Economic) with means of 0 and standard deviations of 0.47 (Social) and 0.22 (Economic). The two variables are not strongly correlated: $r=-0.07$. Second, to measure control of the state legislature, we rely on Klarner's (2013) measure of the proportion of state lower chamber seats held by the Democratic party. ${ }^{6}$ This variable has a median of 0.57 and a standard deviation of 0.23 . Third, to measure gubernatorial control, we rely on Klarner's (2013) measure. The variable takes a value of 0 for a Republican governor, 1 for a Democratic governor, and 0.5 for a nonmajor party governor. The modal state during this time period has a Democratic governor. Finally, state-level demographic changes over time, coupled with the fact that party competition was low in southern states with a high proportion of Black citizens (e.g., Key 1949), demand that we account for the racial make-up of the state population. We use data from the US Census to control for the percentage of the state's population that identifies as Black. ${ }^{7}$ As the data are only available in 10-year intervals, we interpolate linearly between them to get data for every state-year. In 1940, the average state population consisted of $9.3 \%$ of Black citizens, compared to $11.2 \%$ in 2010 . Mississippi boasts the highest percentage of Black citizens, with $49.3 \%$ in 1940 as the all-time high.

\section{Results}

We discuss our results in four stages. First, we examine the results for a series of bivariate regressions. Second, we account for a series of time-varying, within-state

\footnotetext{
have different effects on policy making (Barrilleaux 1997). We discuss the theoretical and empirical differences for the two concepts as applied to our theory and data analysis in the appendix.

${ }^{5}$ Given Angrist and Pischke's (2009) warning that a lagged dependent variable in a model with fixed effects can lead to biased coefficients, we do not include a lagged dependent variable in our models.

${ }^{6}$ As a result, when we estimate models with these control variables, we drop state-years with nonpartisan legislatures.

${ }^{7}$ We also estimated the model using the percentage of the state's population that identifies as nonwhite. The results are nearly identical.
} 


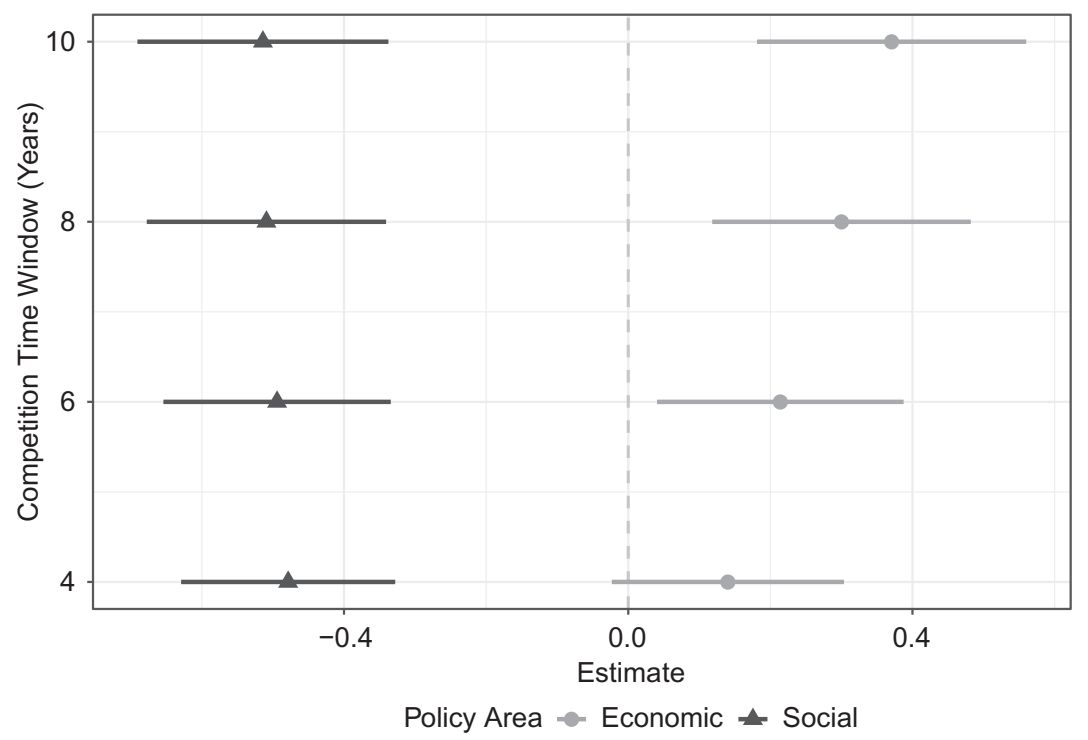

Figure 3. Results of bivariate linear regressions of party competition (the Folded Ranney Index) on policy liberalism for 4-, 6-, 8-, and 10- year levels of aggregation.

Each point corresponds to the coefficient estimate for competition in a linear regression model. The figure includes $95 \%$ confidence intervals for each estimate.

factors that might confound our analysis, demonstrating that our results hold. Third, we probe whether the effects of party competition on policy liberalism have remained constant since the Great Depression. Finally, to account for the fact that the effects of competition on policy liberalism may not be linear, we present the results of a nonparametric regression. ${ }^{8}$

\section{Bivariate Relationship}

We begin by examining the bivariate relationship between party and social and economic policy liberalism. These results are shown in Figure $3 .^{9}$ The $y$-axis refers to the level of aggregation ( $t$ number of years) used to calculate the measure of competition. Each point shows the coefficient for competition in a linear regression model with state and year fixed effects. The shape of the points shows the dependent variable-social or economic liberalism-in the model.

The clearest conclusion from Figure 3 is that the measures of competition relate differently to both dependent variables. Beginning with social liberalism (the

\footnotetext{
${ }^{8}$ We include another analysis in the appendix that divides state-years based on the partisan control of their legislature. We find that, when that one party controls (holding at least $60 \%$ of the chamber) the chamber, party competition pulls both economic and social policy in a countervailing direction. Among chambers controlled by Democrats, higher levels of competition are associated with more conservative social and economic policy. Among chambers controlled by Republicans, competition has the effect of moving both baskets of policies in a more liberal direction.

${ }^{9}$ See Table A.2 in the Appendix for the corresponding regression table.
} 
triangles in Figure 3), the result of each linear regression model is unanimous: increased party competition is associated with less social liberalism. The size of these effects are moderate, with a change across the range in the 6-year competition measure resulting in a 0.25 unit decrease in social liberalism. This is comparable to living in Oklahoma versus Alabama in 2010. These findings stand in stark contrast to the conventional wisdom that competition leads to unambiguously more liberal state policies, suggesting that social conservatives are advantaged in times and places with high levels of party competition.

Next, we examine the relationship between economic liberalism and competition, plotted with circular points. Here, the evidence supports a positive relationship between party competition and economically liberal policies, especially for those models that use a longer time aggregation to calculate competition. The effect sizes are again substantively important, with a change across the range of 6-year competition resulting in a 0.11 unit increase in economic liberalism-roughly the difference between the economic policies of Nevada versus Florida in 2010. In short, the results provide strong support for the hypotheses we have outlined and suggest that Key's original theory holds for economic policy - which, admittedly, was the focus of Key's original analysis-but not for social policy.

\section{Accounting for Potential Confounding Influences}

Of course, the results in Figure 3 do not account for any possible confounding influences. ${ }^{10}$ Figure 4 therefore reproduces the models in the previous figure, controlling for public opinion, gubernatorial partisan control, legislative partisan control, and the percentage of the state's citizens that identify as Black. Table 1 provides numeric regression results.

Looking at the lighter points in Figure 4, the relationships we observed in the previous section persist-and even strengthen-when accounting for the effects of public opinion, the composition of the legislature, the partisanship of the governor, and the racial make-up of the state's residents. There is robust evidence of a positive relationship between party competition and economic policy liberalism once we control for other factors. The size of these effects are substantial. For example, a change across the range of the 4-year Folded Ranney measure yields a 0.36 unit increase in policy liberalism-approximately the difference between Texas and Florida in 2010.

The same is not true for social policy liberalism. While the estimated coefficients continue to be negative (in line with our theory), the uncertainty surrounding those estimates does not enable us to conclude that these effects are distinguishable from a null effect. Perhaps because of the weaker relationship between social policy preferences and social class or the fact that social policy liberalism is more slowmoving than economic policy liberalism, these results provide us with no evidence that social policy liberalism is related to party competition after accounting for a state's public preferences, racial make-up, and the partisan control of state govern-

\footnotetext{
${ }^{10}$ The results we present in this section do not account for the fact that our measures of state policy liberalism have their own measures of uncertainty. We account for this uncertainty in the Appendix, reaching conclusions that support the results presented here.
} 


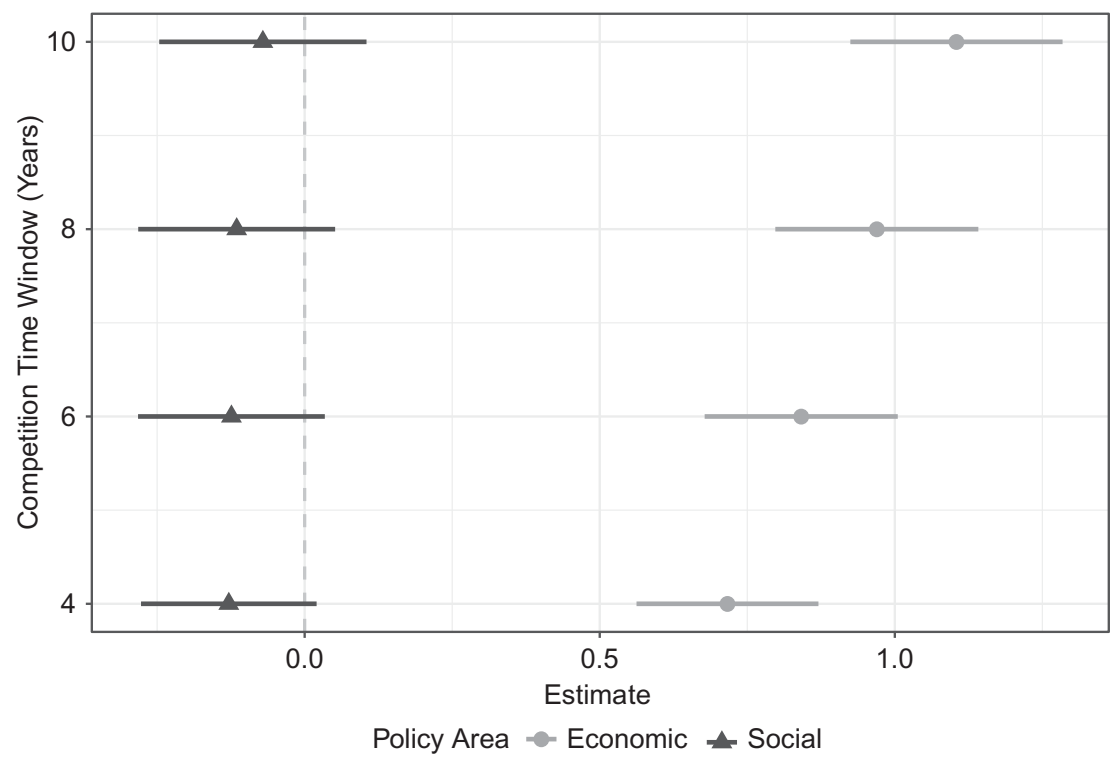

Figure 4. Results of linear regressions of party competition (the Folded Ranney Index) on policy liberalism for 4-, 6-, 8-, and 10-year levels of aggregation. The models include lagged controls for public opinion, legislative control, gubernatorial control, and the percentage of Black citizens, as well as state and year fixed effects.

Each point corresponds to the coefficient estimate for competition in a linear regression model. The figure includes $95 \%$ confidence intervals for each estimate.

ment. While the presence of these control variables does not alter support for the first hypothesis, they do call into question the strength of the second hypothesized relationship.

The control variables generally perform as expected, providing additional evidence in support of the relationship between party competition and policy liberalism discussed above. More Democratic legislative strength is associated with more liberal social, and economic policies. Democratic governors are associated with liberal economic policy, though the relationship between gubernatorial control and social policy is less apparent. The same is generally true for public opinion: more liberal publics tend to get more liberal policies. Similarly, states with a greater proportion of Black citizens tend to have more liberal social and economic policies.

\section{Over-Time Effects}

Party competition in America has ebbed and flowed with time. Key's (1949) analysis of southern politics that first motivated scholars to consider the relationship between competition and policy making examined a place and time that is remarkable for extremely low levels of party competition. As a result, it is reasonable to wonder whether the results we have presented to this point are time-bound.

To investigate whether the relationship between competition and policy liberalism is constant over time, we subsetted our sample repeatedly to include any 1 year and 
the 7 years before and after it. This procedure yields a number of datasets each covering a moving 15-year window of time. For each dataset, we estimated the multivariate specification mirroring that shown in Table 1. Of course, subsetting the data so severely drastically reduces the sample size for any one regression. This, in turn, increased the amount of uncertainty around our regression estimates and their corresponding confidence intervals.

Figure 5 plots the over-time effect of party competition on economic (left-hand panel) and social (right-hand panel) policy liberalism. The value for any 1 year is the coefficient for party competition for the dataset using that year as its midpoint. The shaded parts of the plot correspond to the side of the plot that provides support for our hypothesis (positive effect of competition on economic policy, negative effect on social policy).

There is a considerable amount of over-time variation in the direction and magnitude of the effect of competition on policy liberalism. Party competition appears to have a positive effect on economic policy liberalism (left-hand panel) for the 1930s, 1980s and 1990s. By contrast, increased party competition was associated with less economic liberalism during part of the 1950s and 1970s. While our exepctations are supported for part of the time-series, there are also periods where there is either insufficient-or even contrary-evidence regarding our hypothesis.

The effect of party competition on social policy liberalism (right-hand panel) is not statistically significant for large portions of the time series. During the late 1930s and early 1940s, there is a positive effect, which defies our expectations. This largely corresponds to the results of the previous section, where we also find no statistically significant effect of party competition on social policy liberalism. However, this figure suggests that the relationship has grown stronger-and in line with our hypothesisin recent years. Since 2000, the effect is indeed negative and statistically significant, as predicted by our theory.

In conclusion, this analysis suggests that the relationship between competition and policy liberalism may not be as straightforward as Key and others expected, even when economic policy liberalism is concerned. Rather than an unambiguous linear, positive effect of party competition on policy liberalism, there is a considerable overtime vacillation in the effect. These nonlinearities suggest one reason why the multivariate models in the previous section, which are essentially an aggregation of these time-based models, presented a null result for the relationship between social policy liberalism and party competition.

\section{Accounting for Possible Nonlinearities}

All of the regression models presented so far require a strict assumption: the effect of party competition on policy liberalism is linear. Put differently, these models require us to assume that the effect of competition on liberalism remains constant regardless of whether the amount of party competition is small, medium, or large. ${ }^{11}$ There are reasons to doubt this assumption. For example, the results of the previous section suggest that the relationship between competition and policy liberalism has changed dramatically over recent US history. Or, one might think that there are

\footnotetext{
${ }^{11}$ To put it differently, in a linear model, the effect of an increase in the independent variable from 0.5 to 0.6 produces the same change in the dependent variable as an increase in the independent variable from 0.6 to 0.7 . This assumption makes for a more concise model, but it does not necessarily match reality.
} 
Table 1. Results of linear regressions of party competition (the Folded Ranney Index) on policy liberalism for 4-, 6-, 8-, and 10-year levels of aggregation

Dependent variable

\begin{tabular}{|c|c|c|c|c|c|c|c|}
\hline \multicolumn{4}{|c|}{ Social policy liberalism } & \multicolumn{4}{|c|}{ Economic policy liberalism } \\
\hline (1) & $(2)$ & (3) & (4) & (5) & (6) & (7) & (8) \\
\hline $\begin{array}{r}-0.129^{*} \\
(0.076)\end{array}$ & & & & $\begin{array}{l}0.716^{* * *} \\
(0.079)\end{array}$ & & & \\
\hline & $\begin{array}{c}-0.124 \\
(0.081)\end{array}$ & & & & $\begin{array}{l}0.841^{\text {***}} \\
(0.083)\end{array}$ & & \\
\hline & & $\begin{array}{c}-0.115 \\
(0.085)\end{array}$ & & & & 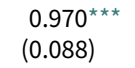 & \\
\hline & & & $\begin{array}{c}-0.071 \\
(0.090)\end{array}$ & & & & $\begin{array}{l}1.104^{\star * *} \\
(0.092)\end{array}$ \\
\hline $\begin{array}{l}0.646^{* * *} \\
(0.039)\end{array}$ & 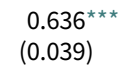 & 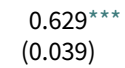 & $\begin{array}{l}0.624^{\text {***}} \\
(0.039)\end{array}$ & & & & \\
\hline & & & & $\begin{array}{l}1.058^{\text {***}} \\
(0.067)\end{array}$ & $\begin{array}{l}1.055^{\text {***}} \\
(0.068)\end{array}$ & $\begin{array}{l}1.046^{\text {***}} \\
(0.069)\end{array}$ & $\begin{array}{l}1.049^{\star * *} \\
(0.070)\end{array}$ \\
\hline 0.022 & 0.020 & 0.019 & 0.024 & $0.044^{\star * *}$ & $0.045^{\star \star \star *}$ & $0.045^{\star * *}$ & $0.044^{* * *}$ \\
\hline$(0.015)$ & $(0.015)$ & $(0.015)$ & $(0.015)$ & $(0.016)$ & $(0.016)$ & $(0.016)$ & $(0.016)$ \\
\hline 0.044 & 0.050 & 0.079 & 0.105 & $1.039^{\star \star \star}$ & $1.042^{* * *}$ & $1.031^{\star \star *}$ & $1.021^{\star * \star}$ \\
\hline$(0.060)$ & $(0.062)$ & $(0.063)$ & $(0.065)$ & $(0.062)$ & $(0.063)$ & $(0.064)$ & $(0.066)$ \\
\hline $0.040^{* \star *}$ & $0.041^{\star * *}$ & $0.040^{* * *}$ & $0.039^{* \star *}$ & $0.022^{\star \star \star}$ & $0.025^{* * *}$ & $0.026^{* \star *}$ & $0.028^{* * *}$ \\
\hline$(0.004)$ & $(0.004)$ & $(0.004)$ & $(0.004)$ & $(0.004)$ & $(0.004)$ & $(0.004)$ & $(0.005)$ \\
\hline 0.091 & 0.089 & 0.070 & 0.092 & $-0.989^{* * *}$ & $-0.980^{* * *}$ & $-0.816^{* * *}$ & $-0.923^{* * *}$ \\
\hline$(0.118)$ & $(0.119)$ & $(0.123)$ & $(0.125)$ & $(0.123)$ & $(0.123)$ & $(0.129)$ & $(0.128)$ \\
\hline Yes & Yes & Yes & Yes & Yes & Yes & Yes & Yes \\
\hline Yes & Yes & Yes & Yes & Yes & Yes & Yes & Yes \\
\hline 3,443 & 3,347 & 3,251 & 3,155 & 3,443 & 3,347 & 3,251 & 3,155 \\
\hline 0.804 & 0.808 & 0.812 & 0.816 & 0.823 & 0.827 & 0.832 & 0.839 \\
\hline 0.797 & 0.800 & 0.805 & 0.809 & 0.817 & 0.821 & 0.826 & 0.832 \\
\hline
\end{tabular}

Note: The models include lagged controls for public opinion, legislative control, gubernatorial control, and the percentage of Black citizens, as well as state and year fixed effects.

${ }^{*} p<0.1$.

${ }^{* *} p<0.05$.

$\star \star \star * 0<0.01$. 

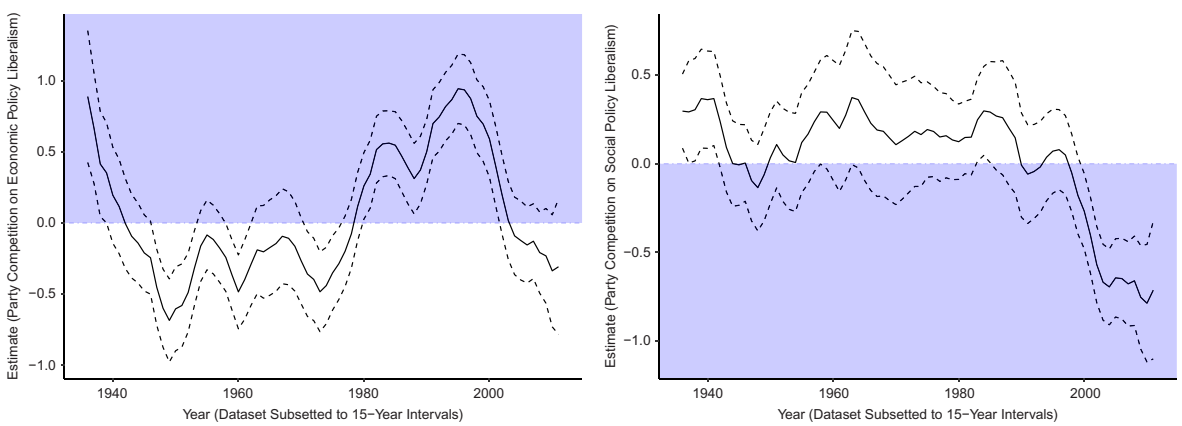

Figure 5. Over-time analysis of the effect of party competition on policy liberalism. The shaded parts of the plot correspond to the side of the plot that provides support for our hypothesis (positive effect of competition on economic policy, negative effect on social policy). The values for any single year are the results of a model conducted on that year and the 7 years to either side. The figure shows that there is a considerable amount of variation in the results over time, but that more often than not, they conform to our main model.

hidden threshold effects: party competition only has an effect up to a certain point or competition only begins to affect policy liberalism once a state reaches a certain amount of competition. To investigate the possibility of nonlinearities such as a threshold or even a direction change (which Figure 5 suggests may be possible), we rely on a nonparametric regression-a model which does not assume a linear relationship between competition and the outcome variable.

Specifically, we fit a generalized additive model (GAM) with a smoothing function for the competition term (Wood 2011). ${ }^{12}$ Compared to other approaches to nonparametric regression, such as local regression (Cleveland, Grosse, and Shyu 1992) or Kendall-Theil regression (Siegel 1982), this method allows us to include all constituent terms, including the fixed effects for state and year. We smooth only the competition term, while all other terms are estimated parametrically. We do so because we have no theoretical reason to expect that their relationships with the dependent variable might be nonlinear. ${ }^{13}$

Figure 6 shows the predicted values of economic (left-hand panel) and social (right-hand panel) policy liberalism ( $y$-axis), given a specific level of party competition ( $x$-axis). ${ }^{14}$ It is evident that strong nonlinearities are in fact present in both relationships.

The general trend for economic policy liberalism (left-hand panel) is positive, in line with our theory: as party competition increases, there is generally an increase in predicted policy liberalism. However, there are important exceptions for this trend. For example, there is an unexpected negative relationship between party competition for Folded Ranney Index values below 0.6: when one party completely dominates and then cedes a small amount of control to the opposition, economic policy is expected to

\footnotetext{
${ }^{12}$ We implement the GAM using the R package mgcv (Wood 2019).

${ }^{13}$ Empirically, we have also found that smoothing these terms makes little difference.

${ }^{14}$ The corresponding regression tables, Tables A.6 and A.7, are included in the appendix.
} 

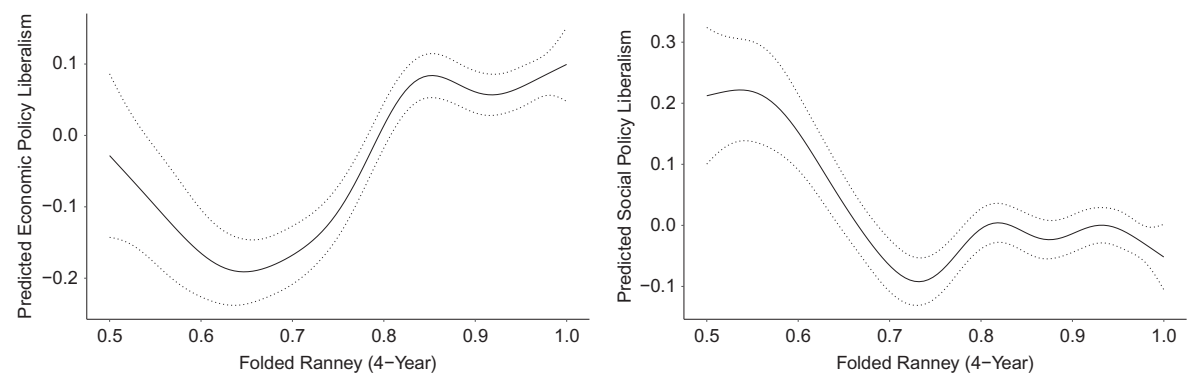

Figure 6. Predicted values of economic (left-hand panel) and social (right-hand panel) policy liberalism, given a certain level of party competition (Folded Ranney Index), from a GAM with a smoothed competition term. The figure includes $95 \%$ confidence intervals. Full regression results are provided in Tables A.6 and A.7.

become more conservative. ${ }^{15}$ As party competition increases further, economic policy becomes more liberal. For values between 0.65 and 0.85 on the Folded Ranney Index, this relationship is almost linear and fully in line with our predictions. As competition reaches its highest level, the effect levels off. ${ }^{16}$ Still, the highest level of party competition is in fact associated with the most liberal economic policies, as our theory predicts.

For social policy (Figure 6, right-hand panel), we observe an overall negative relationship between social policy liberalism and party competition, just as our theory predicts. Policy liberalism is predicted to be at its highest when party competition is extremely low (values below 0.6), and social policy liberalism is predicted to be much lower for higher values of competition than for lower values of competition. When one party enjoys complete dominance, so do its elites, who tend to hold socially liberal values. There is a slight uptick in social policy liberalism for values of competition between 0.7 and 0.8 ; for values above 0.08 , the effect levels off. Evidently, it makes a much bigger difference to go from a state with complete one-party domination to one in which one party tends to win, than going from a reasonably competitive one to a state with razor-thin margins and frequent changes of power (to a lesser extent, this is also true for economic policy liberalism). This figure illustrates the advantage of the nonparametric regression: While the linear model finds no evidence of a relationship between competition and policy liberalism because it has to calculate a linear trend across the entire range of the competition variable, the GAM model shows a strong negative trend in predicted social policy liberalism as party competition moves from its lowest to its highest values. This is the relationship our theory predicts.

\footnotetext{
${ }^{15}$ Such extreme levels of one-party domination predominantly occur in the mid-century South. Of the state-years with a Folded Ranney Index of less than 0.6, 95\% are from the South, and 99\% occur prior to 1980. At this range of the party competition variable, the model is also at its most uncertain, as indicated by the larger confidence interval.

${ }^{16}$ In 2010, a Folded Ranney value of 0.7 or slightly above, might for example, be found in Arkansas, North Dakota, or West Virginia. Values around 0.8 would be in Colorado, Illinois, or South Carolina, whereas Indiana, Maine, or New Jersey are examples for a Folded Ranney Index of about 0.9. The highest values of the Folded Ranney Index in 2010 are Montana, Alabama, and Mississippi, whose legislatures flipped from Democratic to Republican control in 2006, 2010, and 2011, respectively.
} 


\section{Conclusion}

Competition-between parties and in the electoral arena-is one of the most widelyinvoked concepts in the study of political science, especially the comparative study of state politics. Understanding the relationship between this concept and the ideological direction of state policy making is essential for a full understanding of state politics. In this paper, we reexamined the relationship between party competition and state policy liberalism.

This relationship has a long history in the literature, dating back to Key's (1949) suggestion that "A loose factional system lacks the power to carry out sustained programs of action, which almost always are thought by the better element to be contrary to its immediate interests. This negative weakness thus redounds to the benefit of the upper brackets" (308). Scholars have long claimed a positive relationship between party competition and policy liberalism. Our results-drawing upon a longer time period and more expansive set of state policies than any existing study of this relationship-both confirm and challenge Key's intuition.

First, to the extent that Key's hypothesis was carefully limited to economic policy, we have found robust evidence that higher rates of Democratic control of legislatures are positively associated with more liberal economic and social policies. The amount of competition between the parties seeking power in a state matters, in part, because it shapes the ideological valence of the legislation that emerges from government institutions.

At the same time, we have uncovered some evidence of a negative relationship between social liberalism and party competition. This relationship seems to be clearest in recent years and in a model that allows the effect of party competition on policy liberalism to be nonlinear. Given that society's have-nots tend to have cross-cutting preferences on social and economic liberalism, our results extend Key's theory beyond the economic realm. These results provide further evidence for the mechanism stated by Key and additionally suggest that enhanced party competition is particularly beneficial for those individuals who support both socially conservative and economically liberal policies.

As our over-time and nonparametric results plainly show, the relationship between party competition and policy liberalism is far more complicated than the simple theory that has animated so much research on state politics and policy. In many ways, our results truly do raise more questions than answers, particularly with regard to social policy and the temporal dynamics of these relationships. We hope that our findings spark a new wave of research on this storied hypothesis.

Finally, we must also acknowledge research demonstrating some of the most marginal members of Congress to be among the least responsive (Ansolabehere et al. 2001; Deckard 1976; Fiorina 1974; Miller 1970). Comparing the roll call votes of congresspersons to the opinions of their districts, Miller (1970) finds a strong positive relationship between social welfare and civil rights issues; however, when examining the votes of members from marginal districts, there is no relationship between the two. This is further validated in Gulati (2004), who shows legislators from safe seats to be more responsive to the ideological center of their constituencies than those in who ran more competitive races. Members running in competitive races face an incentive to increase their base of support to ensure access to the resources necessary to mount successful campaigns in the future. Our results-which aggregate competition across time-stand in stark contrast to these studies that examine responsiveness at the level of the individual legislator. Future research should examine how the process of 
aggregation from the legislator to the state level affects the relationship between competition and responsiveness.

In sum, however, our results provide an important theoretical and empirical extension of our existing understanding of the relationship between competition and policy liberalism. By demonstrating party competition impacts both economic and social policy making, our results help to broaden our understanding of the connection between the electoral and policy realms of state government, providing further evidence that the obstacles politicians face to keep their jobs affect the types of policies they enact.

Supplementary Material. To view supplementary material for this article, please visit http://dx.doi.org/ 10.1017/spq.2020.2.

Data Availability Statement. Replication materials are available on UNC Dataverse at https://doi.org/ 10.15139/S3/KXN8GN.

Funding Statement. The authors received no financial support for the research, authorship, and/or publication of this article.

Conflict of Interest. The authors declared no potential conflicts of interest with respect to the research, authorship, and/or publication of this article.

Author Biographies. Zachary D. Baumann is Assistant Professor of Political Science at Nebraska Wesleyan University.

Michael J. Nelson is Associate Professor of Political Science and Affiliate Law Faculty at the Pennsylvania State University.

Markus Neumann is a Postdoctoral Research Fellow at the Wesleyan Media Project, Wesleyan University.

\section{References}

Aldrich, John H. 2011. Why Parties? 2nd ed. Chicago: University of Chicago Press.

Aldrich, John H., and John D. Griffin. 2018. Why Parties Matter: Political Competition \& Democracy in the American South. Chicago: University of Chicago Press.

Anderson, R. Bruce. 1997. "Electoral Competition and Southern State Legislatures." In Southern Parties and Elections, 165-81. Tuscaloosa, AL: University of Alabama Press.

Angrist, Joshua D., and Jörn-Steffen Pischke. 2009. Mostly Harmless Econometrics: An Empiricist's Companion. Princeton, NJ: Princeton University Press.

Ansolabehere, Stephen, Jonathan Rodden, and James M. Snyder Jr. 2006. "Purple America." Journal of Economic Perspectives 20 (2):97-118.

Ansolabehere, Stephen, James M. Snyder, Jr. and Charles Stewart, III. 2001 "Candidate Positioning in U.S. HouseElections." American Journal of Political Science, 45 (1): 136-159.

Barrilleaux, Charles. 1997. "A Test of the Independent Influences of Electoral Competition and Party Strength in a Model of State Policy-Making." American Journal of Political Science 41:1462-66.

Barrilleaux, Charles. 2000. "Party Strength, Party Change and Policy-Making in the American States." Party Politics 6 (1):61-73.

Barrilleaux, Charles, Thomas Holbrook, and Laura Langer. 2002. "Electoral Competition, Legislative Balance and American State Welfare Policy." American Journal of Political Science 46 (2):415-72.

Baumann, Zachary, Michael Nelson, and Markus Neumann. 2020. "Replication Data for: Party Competition and Policy Liberalism.” UNC Dataverse. Dataset. https://doi.org/10.15139/S3/KXN8GN.

Berry, William D., Michael Berkman, and Stuart Schneiderman. 2000. "Legislative Professionalism and Incumbent Reelection: The Development of Institutional Boundaries." American Political Science Review 94 (4):859-74.

Bianco, William T. 1994. Trust: Representatives and Constituents. Ann Arbor, MI: University of Michigan Press. 
Blais, André. 2000. To Vote or Not To Vote? Pittsburgh, PA: University of Pittsburgh Press.

Bunche, Beverly. 1991. "The Effect of Constitutional Debt Limits on State Governments' Use of Public Authorities.” Public Choice 68 (1-3):76-95.

Campbell, Bruce A. 1977. "Change in the Southern Electorate." American Journal of Political Science 21 (1):37-64. Carmines, Edward G., and James A. Stimson. 1980. "The Two Faces of Issue Voting." American Political Science Review 74 (1):78-91.

Carpini, Miachael X. Delli, Scott Keeter, and J. David Kennamer. 1994. "Effects of the News Media Environment on Citizen Knowledge of State Politics and Government.” Journalism Quarterly 71 (2):443-56.

Caughey, Devin, and Christopher Warshaw. 2016. "The Dynamics of State Policy Liberalism, 1936-2014." American Journal of Political Science 60 (4):899-913.

Caughey, Devin, and Christopher Warshaw. 2018. "Policy Preferences and Policy Change: Dynamic Responsiveness in the American States, 1936-2014." American Political Science Review 112 (2):249-66.

Cleveland, W. S., E. Grosse, and W. M. Shyu. 1992. "Local Regression Models." In Statistical Models in S, eds. J. M. Chambers and T. J. Hastie. New York, NY: Wadsworth \& Brooks/Cole.

Davies, Andrew Lucas Blaize and Alissa Pollitz Worden. 2009. "State Politics and the Right to Counsel: A Comparative Analysis." Law \& Society Review 43 (1):187-220.

Deckard, Barbara Sinclair. 1976. "Electoral Marginality and Party Loyalty in House Roll Call Voting." American Journal of Political Science 20 (3): 469-481.

Downs, Anthony. 1957. An Economic Theory of Democracy. Harper and Row.

Dye, Thomas R. 1984. "Party and Policy in the States." Journal of Politics 46 (4):1097-116.

Entman, Robert M. 1983. "The Impact of Ideology on Legislative Behavior and Public Policy in the States." Journal of Politics 45 (1):163-82.

Erikson, Robert S., Gerald C. Wright, and John P. McIver. 1989. "Political Parties, Public Opinion, and State Policy in the United States." American Political Science Review 83 (3):729-50.

Erikson, Robert S., Gerald C. Wright, and John P. McIver. 1993. Statehouse Democracy. New York: Cambridge University Press.

Flavin, Patrick. 2011. "Income Inequality and Policy Representation in the American States." American Politics Research 40 (1):29-59.

Flavin, Patrick, and Gregory Shufeldt. 2015. "State Party Competition and Citizen Engagement." Journal of Elections, Public Opinion, and Parties 25 (4):444-62.

Fiorina, Morris P. (1974). Representatives, Roll Calls, and Constituencies. Lexington, MA: D.C. Heath.

Garand, James C. 1985. "Partisan Change and Shifting Expenditure Priorities in the American States, 1945-1978." American Politics Quarterly 13 (4):355-91.

Gilens, Martin. 2009. "Preference Gaps and Inequality in Representation." PS: Political Science and Politics 42(2):335-41.

Gulati, Girish. 2004. "Revisiting the Link Between Electoral Competition and Policy Extremism in the U.S. Congress." American Politics Research 32(5): 495-520.

Hill, Kim Quaile, and Jan E. Leighley. 1992. "The Policy Consequences of Class Bias in State Electorates." American Journal of Political Science 36 (2):351-65.

Hill, Kim Quaile, Jan E. Leighley, and Angela Hinton-Anderson. 1995. "Lower-Class Mobilization and Policy Linkage in the U.S. States." American Journal of Political Science 39 (1):75-86.

Holbrook, Thomas M., and Emily Van Dunk. 1993. "Electoral Competition in the American States." American Political Science Review 87:955-62.

Jennings, Kent M., and Harmon Zeigler. 1970. “The Salience of American State Politics.” American Political Science Review 64 (2):523-35.

Jewell, Malcolm E. 1982. Representation in State Legislatures. Lexington, KY: University Press of Kentucky. Jewell, Malcolm E., and David Breaux. 1988. "The Effect of Incumbency on State Legislative Elections." Legislative Studies Quarterly 13 (4):495-514.

Key, V.O. 1949. Southern Politics in State and Nation. New York, NY: Alfred A. Knopf.

Kingdon, John W. 1966. Candidates for Office: Beliefs and Strategies. New York: Random House.

Klarner, Carl. 2013. .

Lax, Jeffrey R., and Justin H. Phillips. 2009. "How Should We Estimate Public Opinion in The States?" American Journal of Political Science 53 (1):107-21.

Lax, Jeffrey, and Justin Phillips. 2012. "Democratic Deficit in the States." American Journal of Political Science $56(1): 148-56$. 
Miller, Warren E. 1970. "Majority Rule and the Representative System of Government." In Erik Allardt and Stein Rokkan (Eds.), Mass Politics. New York, NY: Free Press.

Pacheco, Julianna. 2013. “The Thermostatic Model of Responsiveness in the American States." State Politics \& Policy Quarterly 13 (3):306-32.

Poterba, James M. 1994. "State Responses to Fiscal Crises: The Effects of Budgetary Institutions and Politics." Journal of Political Economy 102 (4):799-821.

Ranney, Austin. 1965. "Parties in State Politics." In Politics in the American States: A Comparative Analysis, eds. Jacob Herbert and Kenneth N. Vines. New York, NY: Little Brown.

Ranney, Austin. 1976. "Parties in State Politics." In Politics in the American States: A Comparative Analysis, eds. Jacob Herbert and Kenneth N. Vines, 3rd edition, 51-92. Boston: Little Brown.

Rigby, E., and G. C. Wright. 2013. "Political Parties and Representation of the Poor in the American States." American Journal of Political Science 41:1462-66.

Rubin, Donald B. 1987. Multiple Imputation for Nonresponse in Surveys. New York: J. Wiley \& Sons.

Schattschneider, E. E. 1960. The Semi-Sovereign People: A Realist's View of Democracy in America. New York: Holt, Rinehart, and Winston.

Schnakenberg, Keith E., and Christopher J. Fariss. 2014. "Dynamic Patterns of Human Rights Practices." Political Science Research and Methods 2 (1):1-31.

Shufeldt, Gregory, and Patrick Flavin. 2012. "Two Distinct Concepts: Party Competition in Government and Electoral Competition in the American States." State Politics and Policy Quarterly 12 (3):330-42.

Siegel, A.F. 1982. "Robust Regression Using Repeated Medians." Biometrika 69 (1):242-4.

Soroka, Stuart N., and Christopher Wlezien. 2008. "On the Limits to Inequality in Representation." PS: Political Science and Politics 41 (2):319-27.

Stokes, Donald E., and Warren E. Miller. 1962. "Party Government and the Saliency of Congress." Public Opinion Quarterly 26 (4):531-46.

Weber, Ronald E., Harvey J. Tucker, and Paul Brace. 1991. "Vanishing Marginals in State Legislative Elections." Legislative Studies Quarterly 16 (1):29-47.

Wood, S. N. 2011. "Fast Stable Restricted Maximum Likelihood and Marginal Likelihood Estimation of Semiparametric Generalized Linear Models." Journal of the Royal Statistical Society (B) 73 (1):3-36.

Wood, S. N. 2019. mgcv: Mixed GAM Computation Vehicle with Automatic Smoothness Estimation. R package.

Cite this article: Baumann, Zachary D., Michael J. Nelson, and Markus Neumann. 2021. Party Competition and Policy Liberalism. State Politics \& Policy Quarterly 21 (3): 266-285, doi:10.1017/spq.2020.2 